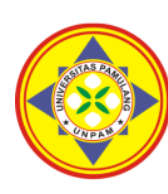

\title{
PENGARUH KOMPETENSI DAN PENGEMBANGAN KARIR TERHADAP KINERJA KARYAWAN PADA PT. GUNATRONIKATAMA CIPTA JAKARTA SELATAN
}

\author{
${ }^{1 *}$ Diana Azwina, ${ }^{2}$ Firda Devi Aulia \\ Universitas Pamulang, Tangerang Selatan, Banten, Indonesia \\ *dosen01741@unpam.ac.id
}

\begin{abstract}
Abstrak
Tujuan penelitian ini adalah untuk mengetahui pengaruh Kompetensi dan Pengembangan Karir baik secara parsial maupun secara simultan terhadap Kinerja Karyawan pada PT. Gunatronikatama Cipta. Metode yang digunakan adalah metode kuantitatif asosiatif. Populasi dalam penelitian adalah seluruh Karyawan PT. Gunatronikatama Cipta dengan sampel sebanyak 85 responden. Data diambil dengan cara memberikan kuesioner dengan teknik sampling jenuh dan dianalisis menggunakan uji asumsi klasik, analisis regresi, analisis koefisien korelasi, analisis koefisien determinasi dan uji hipotesis. Hasil penelitian ini menunjukan bahwa Kompetensi dan Pengembangan Karir secara simultan berpengaruh signifikan terhadap kinerja karyawan dengan persamaan regresi $\mathrm{Y}=3,759+$ $0,512 X 1+0,371 X 2$. Nilai koefisien korelasi diperoleh sebesar 0,722 artinya variabel bebas dengan variabel terikat memiliki hubungan yang kuat dengan koefisien determinasi sebesar 71,5\% maka dapat disimpulkan bahwa variabel Kompetensi (X1) dan Pengembangan Karir (X2) secara bersama-sama berpengaruh terhadap variabel Kinerja Karyawan $(Y)$ sebesar $71,5 \%$ sedangkan sisanya $28,5 \%$ dipengaruhi oleh faktor lain. Uji hipotesis diperoleh nilai Fhitung > Ftabel atau $(102,911>3,11)$ dengan demikian $\mathrm{H} 0$ ditolak dan $\mathrm{H} 3$ diterima, artinya terdapat pengaruh yang signifikan secara simultan antara Kompetensi dan Pengembangan Karir terhadap Kinerja Karyawan pada PT. Gunatronikatama Cipta.
\end{abstract}

Kata Kunci: Kompetensi, Pengembangan Karir, Kinerja Karyawan

\section{Abstract}

The purpose of this study was to determine the effect of Competence and Career Development either partially or simultaneously on Employee Performance at PT. Gunatronikatama Cipta. The method used is associative quantitative method. The population in the study were all employees of PT. Gunatronikatama Cipta with a sample of 85 respondents. Data was taken by giving a questionnaire with saturated sampling technique and analyzed using classical assumption test, regression analysis, correlation coefficient analysis, coefficient of determination analysis and hypothesis testing. The results of this study indicate that Competence and Career Development simultaneously have a significant effect on employee performance with the regression equation $Y=$ $3.759+0.512 X 1+0.371 X 2$. The correlation coefficient value obtained is 0.722 , meaning that the independent variable and the dependent variable have a strong relationship with a coefficient of determination of $71.5 \%$, so it can be concluded that the Competence (X1) and Career Development (X2) variables jointly affect the Employee Performance variable (Y). ) of $71.5 \%$ while the remaining $28.5 \%$ is influenced by other factors. Hypothesis test obtained value Fcount > Ftable or $(102,911$ > 3.11) thus HO is rejected and H3 is accepted, meaning that there is a simultaneous significant influence between Competence and Career Development on Employee Performance at PT. Gunatronikatama Cipta.

Keywords: Competence, Career Development, Employee Performance

\section{PENDAHULUAN}

Dalam suatu sistem operasi perusahaan, potensi sumber daya manusia pada hakekatnya merupakan salah satu modal dan memegang suatu peran yang paling penting dalam mencapai tujuan perusahaan. Oleh karena itu perusahaan perlu mengelola sumber daya manusia sebaik mungkin. Begitu juga untuk menghadapi persaingan saat ini, 
perusahaan harus mampu memiliki sumber daya manusia yang berkualitas. Sumber daya manusia merupakan aspek yang krusial untuk menunjang produktivitas sebuah perusahan agar mampu bertahan di dalam ketatnya persaiangan yang terjadi saat ini. Oleh karena itu, sebuah perusahaan mampu mengelola sumber daya manusia dengan baik agar dapat meningkatkan produktivitas di perusahaan tersebut.

Perusahaan harus dapat memiliki produktifitas yang baik untuk memenuhi target perusahaan yang sudah ditetapkan. Kinerja karyawan yang baik dengan etos kerja yang tinggi akan membantu perusahaan untuk dapat memenuhi target perusahaan tersebut dan membantu perusahaan memperoleh keuntungan, sedangkan bila kinerja karyawan menurun dan buruk maka akan merugikan perusahaan tersebut. Oleh karena itu, maka perusahaan harus dapat mengelola karyawan dengan baik agar kinerja karyawan dapat maksimal, tidak ada konflik antar karyawan, serta tercapainya kepuasan kerja karyawan. Kompetensi merupakan fungsi manajemen sumber daya manusia yang terpenting dan kunci terwujudnya tujuan yang maksimal. Menjaga dan mempertahankan Kompetensi menjadi bagian penting bagi manajer disuatu perusahaan karena kompetensi mampu memberi pengaruh terhadap kinerja karyawan. Untuk mewujudkan kompetensi karyawan yang baik, perusahaan harus memberikan Program pelatihan seperti diadakannya Gasiers Development Program, Daily Coaching.

PT Gunatronikatama Cipta adalah perusahaan yang bergerak dibidang jasa konsultan pajak dan penggajian yang berlokasi di Gedung Plaza Aminta Suite 304 Lt. 3 Kav.10, Jl. TB. Simatupang RT.6 RW.14 Pondok Pinang kec. Kebayoran Lama, Kota Jakarta Selatan 12310. Dilihat dari Kompetensi Karyawan pada PT. Gunatronikatama Cipta banyak Karyawan yang bukan lulusan Akuntansi yang tidak sesuai dengan Requirement Recruitment sehingga kompetensi karyawan masih dibilang minim akan pengetahuan dasar perpajakan dan pengganjian. Banyak Karyawan yang tidak lulus pada program daily coacing sehingga ketika dilakukan evaluasi oleh perusahaan Karyawan tidak siap dan Level yang diberikan rendah dan tidak mencapai target perusahaan yaitu Level 2, sehingga karir dari Karyawan tersebut tidak berkembang.

\section{TINJAUAN PUSTAKA}

\section{Kompetensi}

Pengertian kompetensi dalam organisasipublik maupun privat sangat diperlukan terutama untuk menjawab tuntutan organisasi dimana adanya perubahan yang sangat cepat, perkembangan masalah yang sangat kompleks dan dinamis serta ketidakpastian masa depan dalam tatanan kehidupan masyarakat.

Spencer dan Spencer dalam Wibowo (2014:272) menyatakan bahwa kompetensi merupakan landasan dasar karakteristik orang dan mengindikasikan cara berprilaku atau berpikir, menyamakan situasi, dan mendukung untuk periode waktu cukup lama. Edison et al (2016:17) Kompetensi adalah kemampuan individu untuk melaksanakan suatu pekerjaan dengan benar dan memiliki keunggulan yang didasarkan pada hal-hal yang menyangkut pengetahuan (knowledge), keahlian (skill), dan sikap (attitude)

Dari definisi yang disebutkan di atas, dapat disimpulkan bahwa kompetensi adalah karakteristik individu yang mencakup pengetahuan, keterampilan, dan perilaku yang menghasilkan pekerjaan efektif untuk mencapai tujuan organisasi.

\section{Pengembangan Karir}

Karir merupakan sejarah pekerjaan seseorang atau serangkaian posisi yang dipegangnnya selama kehidupan kerja, karir merupakan suatu urutan promosi atau pemindahan (transfer) ke jabatan-jabatan yang lebih menuntut tanggung jawab atau ke lokasi-lokasi yang lebih baik dalam hierarki hubungan kerja selama 
kehidupan kerja seseorang. Menurut Rivai (2014) "Pengembangan Karir adalah proses peningkatan kemampuan kerja individu yang dicapai dalam rangka mencapai karir yang diinginkan

Pengembangan karir sangat dibutuhkan dan setiap pegawai dalam perjalanan kehidupan kerjanya. Dengan pengembangan karir yang didapatnya ia akan memperoleh kepuasan materi seperti mendapat fasilitas, kenaikan gaji, tunjangan-tunjangan dan sebagainya sedangkan kepuasan non materi seperti perasaan rasa senang, bangga dan sebagainya.

\section{Kinerja Karyawan}

Kinerja karyawan yang diartikan sebagai hasil kerja seorang pekerja, sebuah proses manajemen atau suatu organisasi secara keseluruhan, dimana hasil kerja tersebut harus dapat ditunjukkan buktinya secara konkrit dan dapat diukur, dibandingkan dengan standar yang telah ditentukan. (Sedarmayanti, 2013:260). Adapun indikator yang digunakan meliputi: prestasi kerja, tanggung jawab, ketaatan, kejujuran, dan kerjasama.

\section{METODE}

Jenis penelitian ini menggunakan pendekatan penilaian survey, menurut Arikunto (2013:16) studi survey adalah salah satu pendekatan penelitian yang pada umumnya digunakan untuk pengumpulan data yang luas dan banyak. Survey dengan pendekatan penelitian kuantitatif dengan cara mengumpulkan data melalui instrument penelitian, dan menyebarkan kuisioner kepada karyawan PT. Gunatronikatama Cipta yang hasilnya kemudian diolah melalui program SPSS for windows versi 25 untuk mengetahui pengaruh antara variabel indenpenden Kompetensi dan Pengembangan Karir terhadap variabel dependen kinerja karyawan. Metode tersebut digunakan untuk menguji pengaruh antara dua variabel bebas dan satu varuiabel terikat.

Populasi dalam penelitian ini adalah Karyawan pada PT. Gunatronikatama Cipta
(GASI) sebanyak 85 pegawai atau responden. Metode pengambilan sampel yang digunakan dalam penelitian ini adalah metode Sampling Jenuh (Sensus) adalah teknik penentuan sampel bila semua anggota populasi digunakan sebagai sampel, dalam penelitian ini sebanyak 85 pegawai atau responden. Dalam menganalisis data digunakan uji instrumen, uji asumsi klasik, regresi, koefisien korelasi, koefisien determinasi dan uji hipotesis.

\section{HASIL DAN PEMBAHASAN}

\section{A. Pembahasan Deskriptif}

Dalam menjalankan kegiatan organisasi atau perusahaan perlu memperhatikan Kompetensi para karyawan dimana Kompetensi tersebut berpengaruh bagi Karyawan dan perusahaan untuk menigkatkan produktivitas, dan untuk meningkatkan pengetahuan dari karyawan agar perusahaan semakin berkembang, selain Kompetensi adapula Pengembangan Karir yang berperan penting dalam lingkup kerja Karyawan, pengembangan karir lebih menekankan pada pemberian kesempatan kepada karyawan untuk meningkatkan kemampuan Karyawan untuk meraih tujuan-tujuan pribadinya dalam karir. Karyawan akan lebih terlibat dan berkomitmen dengan perusahaan yang menawarkan kesempatan bagi pertumbuhan dan pengembangan, apabila Perusahaann mampu memotivasi karyawan untuk meningkatkan keahlian maka hal tersebut akan mencapai tujuan sebuah perusahaan.

\section{Keadaan atau kriteria obyek yang diteliti berdasar pada variabel Kompetensi $\left(X_{1}\right)$}

Kompetensi merupakan suatu faktor yang secara langsung berpengaruh terhadap kinerja karyawan, dimana apabila Kompetensi yang diberikan perusahaan baik maka timbal balik dari karyawan akan baik dan memberikan dampak positif bagi perusahaan dikemudian hari. 
Berdasarkan tanggapan 85 responden yang dijadikan obyek penelitian ini, memberikan jawaban yang beragam. Diketahui dari jumlah 10 pernyataan yang diajukan pada variabel Kompetensi, responden yang menjawab sangat setuju dan setuju sebesar $(34,7 \%+48,8 \%)=83,5 \%$. Meskipun rata-rata skor keseluruhan diperoleh 4,15 termasuk pada rentang skala 3,40 - 4,19 dengan kriteria baik. Namun mengingat jumlah responden yang menjawab netral, tidak setuju dan sangat tidak setuju mencapai 16,5\%. Maka untuk lebih baik lagi, perusahaan perlu memberikan perhatian penuh akan perlunya Kompetensi Karyawan dengan tertib menjalankan program Kompetensi yang sudah di adakan setiap hari, perminggu dan perbulan, agar perusahaan dapat bersaing dengan competitor dan menyesuaikan diri dengan kemajuan, perusahaan mampu menggirin Karyawan akan memiliki kemampun sesuai dengan pekerjaannya untuk meningkatkan perusahaan serta mempersiapkan karyawan-karyawan untuk menduduki jabatan tinggi.

2. Keadaan atau kriteria obyek yang diteliti berdasar pada variabel Pengembangan Karir $\left(X_{2}\right)$

Pengembangan

Karir

merupakan suatu upaya yang harus dilakukan agar rencana karir yang sudah dibuat membawa hasil secara optimal. Pengembangan Karir pada dasarnya selalu diharapkan Karyawan dalam sebuah perusahaan, karena dengan Pengembangan Karir Karyawan akan merasa lebih termotivasi untuk menjalankan sebuah pekerjaannya yang lebih baik lagi, apabila suatu pekerjaan dikerjakan lebih baik maka Perusahaan akan berjalan dengan baik dan dapat mencapai tujuan Perusahaan. Hal ini dibuktikan dengan melihat jawaban responden yang menjawab sangat setuju dan setuju sebesar $(38,2 \%+39,9 \%)=$ $78,1 \%$. Memeskipun rata-rata skor diperoleh 4,11 termasuk pada rentang skala 3,40 - 4,19 dengan kriteria baik, namun mengingat jumlah responden yang menjawab netral, tidak setuju dan sangat tidak setuju mencapai $21,9 \%$ maka untuk lebih baik lagi perlu melakukan peningkatan Pengembangan Karir Karyawan sebagai bentuk kepercayaan Perusahaan terhadap Karyawan.

3. Keadaan atau kriteria obyek yang diteliti berdasar pada variabel Kinerja Karyawan (Y)

Kinerja merupakan hasil kerja yang dilakukan oleh karyawan yang berupa kuantitas atau jumlah pekerja, kualitas ataupun mutu pekerjaan dan ketepatan waktu dalam menyelesaikan tugasnya sesuai dengan yang diinginkan perusahaan. Kinerja karyawan dapat diukur dengan seberapa banyak target yang dicapai, seberapa banyak prestasi yang diraih, dan kemampuan dalam menyelesaikan pekerjaan-pekerjaan yang ada dalam perusahaan. Semakin baik kinerja karyawan akan berpengaruh pada prestasi dan nilai diperusahaan. Kinerja karyawan sangat penting bagi perusahaan karena kinerja karyawan merujuk pada keberhasilan dalam menyelesaikan tugas-tugas yang diberikan sehingga tujuan dari organisai atau perusahaan aakan tercapai dan perusahaan akan diuntungkan juga. Oleh karena itu kinerja karyawan tidak untuk didiamkan tetapi harus ditingkatkan agar tujuan dari organisasi atau perusahaan dapat tercapai. Hal ini dibuktikan dengan melihat jawaban responden yang memberikan jawaban atau tanggapan sangat setuju dan setuju sebesar $(28,8 \%+48,5 \%)=$ $77,3 \%$. meskipun rata-rata keseluruhan skor diperoleh sebesar 4,11 dimana nilai tersebut masuk pada rentang skala 3,40 - 4,19 dengan 
kriteria baik, namun mengingat jumlah responden yang memberikan jawaban netral, tidak setuju dan sangat tidak setuju mencapai sebesar $22,7 \%$ maka untuk lebih baik lagi perusahaan perlu memberikan pengertian akan miliki kompetensi yang baik dan berlomba-lomba dalam mencapai prestasi kerja yang optimal.

\section{B. Pembahasan verifikatif}

\section{Pengaruh Kompetensi $\left(X_{1}\right)$ Terhadap} Kinerja Karyawan (Y)

Berdasarkan hasil statistic dapat diketahui variabel Kompetensi $\left(\mathrm{X}_{1}\right)$ memiliki tingkat hubungan atau pengaruh sebesar 0,805 atau sangat kuat terhadap kinerja karyawan $(\mathrm{Y})$ dengan kontribusi pengaruh sebesar 0,647 atau $64,7 \%$. Dari pengujian hipotesis diperoleh $t_{\text {hitung }}>t_{\text {tabel }}$ atau $(12,341>1,988)$ hal tersebut diperkuat dengan nilai signifikansi $0,000<0,05$. hal ini menunjukan bahwa Kompetensi yang tinggi akan meningkatkan Kinerja Karyawan. Untuk itu hipotesis pertama yang menyatakan terdapat pengaruh yang positif dan signifikan secara parsial antara Komeptensi terhadap kinerja karyawan, dapat diterima.

Hasil penelitian ini konsisten dengan hasil penelitian yang dilakukan oleh Nelwati Tanius, Jurnal JENIUS Vol.1 No.3, Juni (2018) dengan judul penelitian "Pengaruh Kompetensi Dan Motivasi Kerja Terhadap Kinerja Guru Pada Yayasan Kristen Bethel Jakarta". Dalam penelitiannya menyimpulkan bahwa Kompetensi berpengaruh positif dan signifikan terhadap kinerja, dengan hasil yang didapat pada uji $t$ variabel pelatihan dengan membandingkan $t$ hitung dengan $t$ tabel, maka diperoleh nilai $t_{\text {hitung }}>t_{\text {tabel }}(13,022>1,98)$ dengan nilai probability signifikansi $0,000<0,05$, sehingga yang artinya $\mathrm{H} 0$ ditolak dan $\mathrm{H}_{1}$ diterima. Sesuai dengan pendapat Edison (2016:17) Kompetensi adalah kemampuan individu untuk melaksanakan suatu pekerjaan dengan benar dan memiliki keunggulan yang didasarkan pada hal-hal yang menyangkut pengetahuan (knowledge), keahlian (skill), dan sikap (attitude).

Dengan adanya pendapat tersebut dapat disimpulkan bahwa agar Kompetensi Karyawan meningkat Perusahaan harus memberikan perhatian penuh akan perlunya pengetahuan. Untuk meningkatkan Kompetensi yaitu dengan cara Karyawan dengan tertib menjalankan program Kompetensi yang sudah di adakan setiap hari, perminggu dan perbulannya yang sudah di sediakan oleh perusahaan sehingga kinerja Karyawan maksimal dan memiliki pengetahuan serta keahlian yang baik.

2. Pengaruh Pengembangan Karir $\left(X_{2}\right)$ Terhadap Kinerja Karyawan (Y)

Berdasarkan hasil statistik dapat dketahui Pengembangan Karir $\left(\mathrm{X}_{2}\right)$ memiliki tingkat hubungan atau pengaruh sebesar 0,790 atau kuat terhadap kinerja karyawan $(\mathrm{Y})$ dengan kontribusi pengaruh sebesar 0,624 atau $62,4 \%$. Hal ini menunjukan bahwa Pengembangan Karir yang tinggi akan meningkatkan kinerja karyawan. Dari pengujian hipotesis diperoleh $t_{\text {hitung }}>t_{\text {tabel }}$ atau $(11,731>$ $1,988)$ hal tersebut diperkuat dengan nilai signifikansi $0,000<0,05$, untuk itu hipotesis kedua yang menyatakan tardapat pengaruh yang positif dan signifikan secara parsial antara Pengembangan Karir terhadap Kinerja Karyawan, dapat diterima.

Hasil penelitian ini sejalan dengan penelitian Bachtiar Arifudin Husain, Jurnal Ekonomi Efektif, Vol 3, No. 1 (2020) Oktober 2020 dengan judul "Pengaruh Lingkungan Kerja dan Pengembangan Karir Karyawan Terhadap Kinerja Karyawan Pada PT. Telkom Indonesia Persero. Tbk" dimana hasil hipotesis membuktikan bahwa secra parsial variabel 
Pengembangan Karir $\quad\left(\mathrm{X}_{2}\right)$ mempunyai pengaruh secara positif dan signifikan terhadap kinerja karyawan (Y), dengan didapat hasil uji $t$ variabel Pengembangan Karir dengan membandingka $t$ hitung dan $t_{\text {tabel, }}$ maka diperoleh nilai $t_{\text {hitung }}>t_{\text {tabel }}$ $(3.441>1.994)$ dengan nilai signifikansi $0,000<0,05$. adanya angka positif dan signifikan artinya apabila Pengembangan Karir ditingkatkan maka akan meningkat kinerja karyawan pada PT. Gunatronikatama Cipta dan ini sesuai dengan pendapat Rivai (2014) Pengembangan Karir adalah proses peningkatan kemampuan kerja individu yang dicapai dalam rangka mencapai karir yang diinginkan.

Dengan adanya pengertian tersebut dapat disimpulkan bahwa Pengembangan Karir pada dasarnya selalu diharapkan Karyawan dalam sebuah perusahaan, karena dengan Pengembangan Karir Karyawan akan merasa lebih termotivasi untuk menjalankan sebuah pekerjaannya yang lebih baik lagi, apabila suatu pekerjaan dikerjakan lebih baik maka Perusahaan akan berjalan dengan baik dan dapat mencapai tujuan Perusahaan.

3. Pengaruh Kompetensi $\left(X_{1}\right)$ dan Pengembangan Karir $\left(X_{2}\right)$ Terhadap Kinerja Karyawan (Y)

Berdasarkan hasil penelitian, menunjukkan bahwa Kompetensi $\left(X_{1}\right)$ dan Pengembangan Karir $\left(X_{2}\right)$ berpengaruh positif terhadap kinerja karyawan PT. Gunatronikatama Cipta, dengan persamaan regresi adalah $\mathrm{Y}=3,759+0,512 \mathrm{X}_{1}+0,371 \mathrm{X}_{2}$ hasil analisis regresi menunjukan koefisien Kompetensi sebesar 0,512, Pengembangan Karir sebar 0,371 semuanya bertanda positif. Hal ini diartikan bahwa Kompetensi, Pengembangan Karir tinggi maka akan semakin baik pula kinerja karyawan. Demikian pula sebaliknya, jika Kompetensi, Pengembangan
Karir rendah maka akan semakin rendah pula kinerja karyawan. Kontribusi pengaruh sebesar 0,715 atau $71,5 \%$ sedangkan sisanya $28,5 \%$ dipengaruhi oleh faktor lain.

Dari pengujian hipotesis menggunakan uji statistic diperoleh nilai $F_{\text {hitung }}>F_{\text {tabel }}(102,911>3,11)$ hal ini diperkuat dengan nilai probability signifikansi $0,000<0,05$, untuk itu hipotesis ketiga yang menyatakan pengaruh positif dengan signifikansi secara simultan antara Kompetensi dan Pengembangan Karir terhadap kinerja karyawan, dapat diterima.

Hasil penelitian ini konsisten dengan penelitian Anastasia Lisa Bintari, jurnal Ekonomi Vol. 6, No. 4 (2018) dengan judul "Pengaruh Kompetensi Dan Pengembangan Karir Terhadap Kinerja Karyawan Pada PT. Purnama Indonesia Sidoarjo". Hasil pengujian menunjukan bahwa Kompetensi dan Pengembangan Karir sangat berpengaruh terhadap kinerja karyawan. Analisa data dengan menggunakan analisis regresi kinear berganda dengan taraf signifikan $\alpha=$ 0,05, hasil penelitian menunjukan bahwa Kompetensi $\left(X_{1}\right)$ memiliki statistik uji $t_{\text {hitung sebesar 3,501 dan }}$ signifikansi sebesar 0,001 karena nilai t sig $=0,001<0,05$ dengan demikian dapat dinyatakan bahwa Kompetensi berpengaruh terhadap kinerja karyawan. Pengembangan Karir $\left(\mathrm{X}_{2}\right)$ memiliki statistic uji $t_{\text {hitung }}$ sebesar 2,069 dan signifikansi sebesar 0,047, karena nilai $\mathrm{t}$ sig $=0,047<0,05$, dengan demikian dapat dinyatakan bahwa Pengembangan Karir berpengaruh terhadap kinerja karyawan. Hal ini menunjukan bahwa Komepetensi dan Pengembagan Karir berpengaruh positif dan signifikan terhadap kinerja karyawan PT. Purnama Indonesia. $\mathrm{Hal}$ ini sesuai dengan pendapat Hasibuan (2017:94) yang berpendapat bahwa Kinerja adalah hasil kerja yang 
dicapai seseorang didasarkan atas kecakapan, pengalaman dan kesungguhan serat waktu.

\section{PENUTUP}

\section{Kesimpulan}

Berdasarkan hasil penelitian pada PT. Gunatronikatama Cipta, maka dapat diambil kesimpulan sebagai berikut ini:

1. Kompetensi berpengaruh signifikan terhadap Kinerja Karyawan dengan persamaan regresi $Y=4,703+0,855 X_{1}$, nilai koefisien korelasi sebesar 0,805 artinya kedua variabel memiliki tingkat hubungan yang kuat dengan koefisien determinasi sebesar $64,7 \%$. Uji hipotesis diperoleh $\mathrm{t}$ hitung $>\mathrm{t}$ tabel atau $(12,341$ $>1,988)$, hal ini diperkuat dengan probability signifikansi $0,000<0,05$, dengan demikian $\mathrm{H}_{0}$ ditolak dan $\mathrm{H}_{1}$ diterima artinya terdapat pengaruh signifikan antara Kompetensi terhadap Kinerja Karyawan di PT. Gunatronikatama Cipta.

2. Pengembangan Karir berpengaruh signifikan terhadap Kinerja Karyawan dengan persamaan regresi $\mathrm{Y}=11,287+$ $0,707 \mathrm{X}_{2}$ nilai koefisien korelasi sebesar 0,790 artinya kedua memiliki tingkat hubungan yang sedang dengan koefisien determinasi sebesar $62,4 \%$. Uji hipotesis diperoleh $\mathrm{t}$ hitung $>\mathrm{t}$ tabel atau $(11,731>1,988)$, hal ini diperkuat dengan probability signifikansi $0,000<$ 0,05 , dengan demikian $\mathrm{H}_{0}$ ditolak dan $\mathrm{H}_{2}$ diterima artinya terdapat pengaruh signifikan antara Pengembanagan Karir terhadap Kinerja Karyawan di PT. Gunatronikatama Cipta.

3. Kompetensi dan Pengembangan Karir berpengaruh signifikan terhadap Kinerja Karyawan dengan persamaan

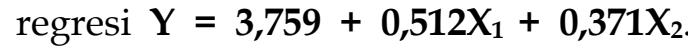
Nilai koefisien korelasi diperoleh sebesar 0,846 artinya variabel bebas dengan variabel terikat memiliki tingkat hubungan yang sangat kuat dengan koefisien determinasi 0,715 atau pengaruh secara simultan sebesar 71,5\% sedangkan sisanya sebesar 28,5\% dipengaruhi faktor lain. Uji hipotesis diperoleh nilai $F_{\text {hitung }}>F_{\text {tabel }}$ atau $(102,911$ $>3,11$ ), hal tersebut juga diperkuat dengan probability signifikansi $0,000<$ 0,05 . Dengan demikian $\mathrm{H}_{0}$ ditolak dan $\mathrm{H}_{3}$ diterima. Artinya terdapat pengaruh signifikan secara simultan antara Kompetensi dan Pengembangan Karir terhadap kinerja karyawan di PT. Gunatronikatama Cipta.

\section{Saran}

1. Variabel Kompetensi untuk jawaban pernyataan responden yang paling lemah adalah nomor 9 dengan nilai rata - rata 3,96 yaitu Rekan kerja cepat dan tanggap apabila saya meminta bantuan. Atas data responden tersebut penulis memberikan saran perusahaan untuk menambah pelatihan mengenai " 7 Habbit of Highly effective people" tujuannya agar Karyawan mengerti akan tujuan sebuah team.

2. Variabel Pengembangan Karir untuk jawaban pernyataan responden yang paling lemah adalah nomor 6 dengan nilai rata - rata 3,58 yaitu Saya nyaman untuk bekerja dalam jangka waktu yang lama. Atas data responden tersebut penulis memberikan saran untuk perusahaan sebaiknya menambah kebijakan terkait dengan memberikan reward ketika Karyawan memiliki pencapaian tertentu agar Karyawan termotivasi dan nyaman untuk berkarir diperusahaan.

3. Variabel Kinerja Karyawan untuk jawaban pernyataan responden yang paling lemah adalah nomor 4 dengan nilai rata - rata 3,66 yaitu Kuantitas / beban kerja yang diberikan kepada saya sesuai dengan kemampuan saya. Atas data responden tersebut penulis memberikan saran perusahaan menjalankan uji kompetensi atas program pelatihan yang sudah dijalankan dan memberikan perhatian penuh terhadap program yang sudah dijalankan. 
DAFTAR PUSTAKA

Arifudin, B. (2020). Pengaruh Lingkungan Kerja dan Pengembangan Karir Karyawan Terhadap Kinerja Karyawan Pada PT. Telkom Indonesia Persero. Tbk. Jurnal Ekonomi Efektif, Vol. 3 No. 1.

Arikunto, S. (2013). Prosedur Penelitian: Suatu Pendekatan Praktik. Jakarta: Rineka Cipta.

Asmalah, L. (2019). Pengaruh Kompetensi, Pengembangan Karier dan Lingkungan Kerja terhadap Kepuasn Kerja Karyawan pada PT. Boga Lestari Sentosa Indonesia. Jurnal Ekonomi Efektif, Vol. 1 No. 3.

Bintari, A. (2018). Pengaruh Kompetensi Dan Pengembangan Karir Terhadap Kinerja Karyawan Pada PT. Purnama Indonesia Sidoarjo. Jurnal Ilmu Manajemen, Vol. 6 No. 4.

Dessler. (2015). Manajemen Sumber Daya Manusia. Jakarta: Indeks.

Edison. (2017). Manajemen Sumber Daya Manusia. Bandung: Alfabeta.

Feriyanto. (Kebumen). Penghantar Manajemen (3 in 1). 2015: Mediatera.

Ghozali, I. (2016). Aplikasi Analisis Multivariete IBM SPSS 23. Semarang: Universitas Diponegoro.

Guruh, M. (2018). Pengaruh Kompetensi Terhadap Kinerja Guru Pada SMK Kartika X-2. Jurnal JENIUS, Vol. 1 No. 2.

Guruh, M. (2019). Pengaruh Motivasi Kerja, Kompetensi, Dan Kompensasi Terhadap Kinerja Karyawan Pada PT Finansia Multi Finance Cabang Kedoya. JENIUS (Jurnal Ilmiah Manajemen Sumber Daya Manusia), 2(3), 343-354.

Hasibuan, M. (2016). Manajemen Sumber Daya Manusia. Jakarta: PT Bumi Aksara.

Hayati, A. (2017). pengaruh kompetensi, pengembangan karier dan lingkungan kerja terhadap kepuasan kerja karyawan pada PT. BOGA Lestari Sentosa Indonesia. Jurnal ekonomi, 1 .
Hermawati, R., \& Hidayat, R. R. (2019). Pengaruh Kepemimpinan Dan Kompetensi Terhadap Produktivitas Pegawai PPSU (Studi Kasus Di Penanganan Prasarana Dan Sarana Umum Pada Kelurahan Lebak Bulus Jakarta Selatan). JENIUS (Jurnal Ilmiah Manajemen Sumber Daya Manusia), 2(2), 189-211.

Lewenussa, R., \& Rawi, R. D. P. (2020). Discriminant Study with Classification of Underdeveloped and Developing City Districts in West Papua Province. Ekuilibrium: Jurnal Ilmiah Bidang Ilmu Ekonomi, 15(2), 103117.

Lilis, S. (Bandung). Manajemen Sebuah Pengantar Sejarah, Tokoh, Teori dan Praktik. 2014: La Goods Publishing.

Mangkunegara, A. (2015). Sumber Daya Manusia Perusahan. Bandung: Remaja Rosdakarya.

Mogi, A. (2018). Pengaruh Kompetensi Guru, Motivasi Guru Dan Lingkungan Sekolah Terhadap Hasil Belajar Siswa Sma Tunas Indonesia Bintaro. Jrnal JENIUS, Vol. 1 No. 2.

Nurjaya, N., Affandi, A., Ilham, D., Jasmani, J., \& Sunarsi, D. (2021). Pengaruh Kompetensi Sumber Daya Manusia Dan Kemampuan Pemanfaatan Teknologi Terhadap Kinerja Aparatur Desa Pada Kantor Kepala Desa Di Kabupaten Gunungkidul, Yogyakarta. JENIUS (Jurnal Ilmiah Manajemen Sumber Daya Manusia), 4(3), 332-346.

Permatasari, R. J. (2019). Pengaruh Komunikasi Dan Disiplin Kerja Terhadap Kinerja Karyawan Pada PT. Hokben Alam Sutera Tangerang. JENIUS (Jurnal Ilmiah Manajemen Sumber Daya Manusia), 2(3), 410-418.

Rawi, R. D. P., \& Kadir, M. A. A. (2018). Analisis Hubungan Motivasi Terhadap Kinerja Pegawai (Studi Kasus Pada Kantor Wali Kota Sorong Papua Barat). Manajemen Dewantara, 2(2), 87-94. 
Rivai, V. (2014). Manajemen Sumber Daya Manusia untuk Perusahaan dari Teori ke Parkit. Jakarta: PT. Rajawali Pers.

Sedarmayanti. (2017). Perencanaan dan Pengembangan Sumber Daya Manusia. Bandung: PT. Refika Aditama.

Shaputra, H. (2015). Pengaruh Kompetensi, Komitmen dan Pengembangan Karir terhadap kinerja Karyawan PT. Bank Rakyat Indonesia. Jurnal Tepak Manajemen Bisnis, Vol. 7 No.1.

Sudiarto. (2019). Pengaruh Kompetensi dan Motivasi terhadap Kinerja Guru pada SMKN 8 Jakarta - Selatan. Jurnal Ekonomi Efektif, Vol.1 No.3.

Sugiyono. (2016). Metode Penelitian Kuantitatif dan RED. Bandung: Alfabeta.

Suprianto, S. (2019). Pengaruh Kompetensi Pedagogik Dan Motivasi Kerja Terhadap Kinerja Guru SMP Negeri 17-Kota Tangerang Selatan. JENIUS
(Jurnal Ilmiah Manajemen Sumber Daya Manusia), 2(3), 355-373.

Sutoro, M. (2019). Pengaruh Pengembangan Karir terhadap Kinerja Karyawan pada PT. BCA Finance Jakarta. Jurnal Ekonomi Efektif, Vol. 2 No.1.

Sutrisno, E. (2016). Manajemen Sumber Daya Manusia. Jakarta: Prenadamedia Group.

Suwanto. (2017). Pengaruh penilaian Kinerja dan Pengembangan Karir terhadap Motivasi Kerja pada PT. Tirta Varia Inti Pratama. Jurnal Pendidikan, Vol.2 No.3.

Tanius, N. (2018). Pengaruh Kompetensi Dan Motivasi Kerja Terhadap Kinerja Guru Pada Yayasan Kristen Bethel Jakarta. Jurnal JENIUS, Vol. 1 No. 3.

Wibowo. (2017). Manajemen Kinerja, Edisi ke 5. Depok: PT. Raja Grafindo Persada.

Widodo, S. (2015). Manajemen Pengembangan Sumber Daya Manusia. Yogyakarta: Pusaka Pelajar. 